\title{
Nereida ignava gen. nov., sp. nov., a novel aerobic marine $\alpha$-proteobacterium that is closely related to uncultured Prionitis (alga) gall symbionts
}

\author{
M. J. Pujalte, ${ }^{1,2}$ M. C. Macián, ${ }^{1,2}$ D. R. Arahal, ${ }^{2,3}$ W. Ludwig, ${ }^{4}$ K. H. Schleifer ${ }^{4}$ \\ and E. Garay ${ }^{1,2,3}$ \\ ${ }^{1}$ Instituto Cavanilles de Biodiversidad y Biología Evolutiva, Universitat de València, València, \\ Spain \\ ${ }^{2,3}$ Departamento de Microbiología y Ecología² and Colección Española de Cultivos Tipo \\ $(\mathrm{CECT})^{3}$, Facultad de Biología, Universitat de València, Campus de Burjassot, \\ 46100 València, Spain \\ ${ }^{4}$ Lehrstuhl für Mikrobiologie, Technische Universität München, Am Hochanger 4, D-85350 \\ Freising, Germany
}

\begin{abstract}
A Gram-negative, slightly halophilic, non-pigmented, strictly aerobic, chemo-organotrophic bacterium was isolated from Mediterranean sea water off the Spanish coast near Valencia. This strain was poorly reactive, being unable to grow in most carbon sources analysed in minimal medium. However, good growth was observed when more complex media and longer incubation times were used. Phylogenetic analysis based on an almost complete 16S rRNA gene sequence placed strain $2 \mathrm{SM} 4^{\top}$ within the Roseobacter group, in the vicinity of uncultured bacteria described as gall symbionts of several species of the red alga Prionitis. Sequence similarity values between strain $2 \mathrm{SM} 4^{\top}$ and the closest neighbouring species were below $95 \cdot 0 \%$. The cellular fatty acid composition of the Mediterranean strain confirmed its position within the

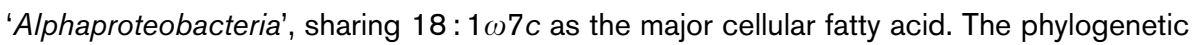
distance from any taxon with a validly published name and also a number of distinguishing features support the designation of strain $2 \mathrm{SM} 4^{\top}$ as representing a novel genus and species, for which the name Nereida ignava gen. nov., sp. nov. is proposed. The type strain is $2 \mathrm{SM} 4^{\top}$ $\left(=\right.$ CECT $5292^{\top}=$ DSM $16309^{\top}=$ CIP $108404^{\top}=$ CCUG $\left.49433^{\top}\right)$.
\end{abstract}

The Roseobacter group classified within the order 'Rhodobacterales' in the last release of the Taxonomic Outline of the Prokaryotes (Garrity et al., 2003) includes bacteria from a large number of marine environments (a Mediterranean coastal lagoon, an Atlantic Ocean central gyre, the Black Sea, the North Sea and Antarctic sea ice, among others) that have diverse types of metabolism (phototrophy, aerobic sulfite oxidation, organic sulfur compound degradation and lignin degradation) (Benlloch et al., 1995; Bowman et al., 1997; Gonzalez et al., 1997; Gosink \& Staley, 1995; WagnerDöbler et al., 2004). Thus it is clear that these bacteria play an important role in carbon, sulfur and nitrogen cycling

Published online ahead of print on 4 October 2004 as DOI 10.1099/ ijs.0.63442-0.

The GenBank/EMBL/DDBJ accession number for the 16S rRNA gene sequence of Nereida ignava CECT $5292^{\top}$ is AJ748748.

Electron micrographs of strain $2 \mathrm{SM} 4^{\top}$ and a table of differential oxidation profiles on Biolog GN plates are available as supplementary material in IJSEM Online.
(Gonzalez et al., 1999, 2000). The Roseobacter group also includes a number of environmental clones of uncertain biological significance. Several of these clones have been found consistently in geographically distant sites around the oceans of the world; to date, most remain uncultured and without cultured neighbours. The use of innovative culturing methods has allowed the cultivation of various $\alpha$-proteobacteria, such as 'Pelagibacter ubique' of the SAR11 clade (Rappé et al., 2002).

Several bacteria belonging to the Roseobacter group have been described as epiphytes or symbionts of marine organisms such as bryozoans and algae (micro- and macroalgae). Nevertheless, the impact of such associations remains to be determined. In the red algal genus Prionitis, gall formation is known to be induced by bacteria phylogenetically related to the Roseobacter group (Ashen \& Goff, 1996, 1998). It is well known that bacterial gall formation is species specific, and coevolution between the red algal hosts and their associated bacteria has been reported (Ashen \& Goff, 2000). However, the physiological 
function of these galls has not been determined, and the bacteria have not been cultivated as pure cultures.

The present study reports on one bacterium, strain $2 \mathrm{SM} 4^{\mathrm{T}}$, isolated from Mediterranean sea water, that is phylogenetically related, in terms of $16 \mathrm{~S}$ rRNA gene sequences, to the gall symbionts. Strain $2 \mathrm{SM} 4^{\mathrm{T}}$ was obtained from sea water surrounding cultivated oysters 2-3 miles off the Mediterranean coast near Valencia (Spain). In a previous phenotypic study, it clustered in phenon 40 (Ortigosa et al., 1994) together with other unreactive marine bacteria, and remained unidentified.

Cultures were maintained on marine agar (MA; Difco) slants at room temperature and as suspensions in marine broth 2216 (MB; Difco) plus $10 \%(\mathrm{v} / \mathrm{v})$ glycerol at $-80^{\circ} \mathrm{C}$. They were routinely grown at $24-26^{\circ} \mathrm{C}$ on MA or MB. Most of the phenotypic characterization methods were performed as previously described (Macián et al., 2001). The organism was unable to ferment sugars under anaerobic conditions, as determined on anaerobic Hugh \& Leifson $\mathrm{O} / \mathrm{F}$ medium (Difco) with half-strength artificial sea water (ASW) $\left(400 \mathrm{mM} \mathrm{NaCl}, 100 \mathrm{mM} \mathrm{MgSO}_{4} .7 \mathrm{H}_{2} \mathrm{O}, 20 \mathrm{mM}\right.$ $\mathrm{KCl}$ and $20 \mathrm{mM} \mathrm{CaCl}_{2} \cdot \mathrm{H}_{2} \mathrm{O}$; Baumann \& Baumann, 1981). Strain $2 \mathrm{SM} 4^{\mathrm{T}}$ exhibited catalase and oxidase activities. It did not reduce nitrate to nitrite in nitrate broth and it was also unable to grow in the denitrification medium of Baumann (Baumann \& Baumann, 1981). Thus, it is a strict aerobe. Strain $2 \mathrm{SM} 4^{\mathrm{T}}$ was mesophilic, growing from 13 to $28^{\circ} \mathrm{C}$, but not at 4 or $37^{\circ} \mathrm{C}$ on solid medium (MA).

Cells grew on MA as unpigmented, regular, opaque colonies. Colonies were pinpoints less than $1 \mathrm{~mm}$ in diameter after $48 \mathrm{~h}$ incubation. The cells neither swarmed nor luminesced. Strain $2 \mathrm{SM} 4^{\mathrm{T}}$ required sea water-based media for growth, being unable to grow in salt tolerance agar $(1 \%, \mathrm{w} / \mathrm{v}$, tryptone; $0.3 \%$, w/v, yeast extract; $1.5 \%, \mathrm{w} / \mathrm{v}$, agar) with the addition of $\mathrm{Na}^{+}, \mathrm{K}^{+}, \mathrm{Mg}^{2+}$ and $\mathrm{Ca}^{2+}$ ions either as chlorides or with the substitution of $\mathrm{MgCl}_{2}$ by $\mathrm{MgSO}_{4}$, but showed good growth on MB and MA. The salinity range supporting growth on MA, diluted or supplemented with $\mathrm{NaCl}$ as reported in Macián et al. (2005), was between 1.36 and $8 \%(\mathrm{w} / \mathrm{v})$ total salts. Thus, strain $2 \mathrm{SM} 4^{\mathrm{T}}$ is a slight halophile with complex ionic requirements similar to those of the recently described species Thalassobacter stenotrophicus (Macián et al., 2005).

Isolate $2 \mathrm{SM}^{\mathrm{T}}$ was negative for the following enzymic activities: arginine dihydrolase, lysine decarboxylase, ornithine decarboxylase, urease, $\mathrm{H}_{2} \mathrm{~S}$ production from thiosulfate, indole production from tryptophan and sulfite oxidation (Gonzalez et al., 1999). No hydrolytic activities were detected on the following substrates: casein, gelatin, starch, alginate, agar, DNA, Tween 80 and lecithin. These tests were performed in media supplemented with marine salts (MA or half-strength ASW). DNase agar and Tween 80 agar, supplemented with half-strength ASW, and MB plus $12 \%(\mathrm{w} / \mathrm{v})$ gelatin did not support growth of strain $2 \mathrm{SM} 4^{\mathrm{T}}$.
Utilization of several compounds as sole carbon and energy sources was analysed on basal medium agar [BMA: $50 \mathrm{mM}$ Tris/ $\mathrm{HCl}, \mathrm{pH} 7 \cdot 5 ; 19 \mathrm{mM} \mathrm{NH}_{4} \mathrm{Cl} ; 0 \cdot 33 \mathrm{mM} \mathrm{K}_{2} \mathrm{HPO}_{4} \cdot 3 \mathrm{H}_{2} \mathrm{O}$; $0.1 \mathrm{mM} \mathrm{FeSO} \mathrm{F}_{4} .7 \mathrm{H}_{2} \mathrm{O}$ and $1.3 \%(\mathrm{w} / \mathrm{v})$ purified agar (Oxoid) on half-strength ASW; Baumann \& Baumann, 1981]. The BMA was supplemented with $0 \cdot 1 \mathrm{~g}$ yeast extract $1^{-1}$ since the organism was originally reported as being unable to grow on minimal medium (Ortigosa et al., 1994). Carbohydrates were added at $2 \mathrm{~g} \mathrm{l}^{-1}$ whereas the remaining compounds were added at $1 \mathrm{~g} \mathrm{l}^{-1}$. Cells were incubated for 30 days. Positive control plates were prepared with $5 \mathrm{~g}$ yeast extract $1^{-1}$ whereas negative control plates consisted of BMA plus $0 \cdot 1 \mathrm{~g}$ yeast extract $1^{-1}$. Growth was scored as negative when growth was equal to, or less than, that in the negative control plates. In general, strain $2 \mathrm{SM} 4^{\mathrm{T}}$ utilized few substrates and was slowly reactive, since all positive results were recorded after 14 days incubation; even then, the amount of cell mass obtained was scarce in many instances. Detailed results of the nutritional tests are listed in the species description.

The substrate-oxidation profile was obtained by using the Biolog system according to the recommendations of the manufacturer, except for the preparation of the inoculum. Strain $2 \mathrm{SM}^{\mathrm{T}}$ was grown for 2-3 days on MA, since it did not grow on Biolog Universal growth medium plus blood, and the inoculating fluid was half-strength ASW. The plate was incubated at $28^{\circ} \mathrm{C}$ for 2 days. Positive oxidation was obtained only with maltose; borderline reactions were observed with adonitol, lactulose, D-mannitol, D-raffinose, turanose, $\gamma$-hydroxybutyric acid, $\alpha$-ketovaleric acid, Lalaninamide, DL-carnitine, inosine and 2-aminoethanol. This behaviour is in agreement with the slow growth and narrow utilization pattern of strain $2 \mathrm{SM} 4^{\mathrm{T}}$ with regard to sole carbon and energy sources in BMA.

Cell morphology and motility were examined by using optical, scanning electron and transmission electron microscopy. Cells grown on MA for 2-3 days were suspended in half-strength ASW and observed on wet mounts by using phase-contrast microscopy (using Leica MBRD apparatus). In parallel, cell suspension was adsorbed onto Isopore (Millipore) membrane filters, dehydrated with a graded series of ethanol [50, 80 and $100 \%(\mathrm{v} / \mathrm{v})$ ethanol], criticalpoint dried with $\mathrm{CO}_{2}$ (Autosamdri-814; Tousimis) and sputter-coated (using Bio-Rad apparatus) with a goldpalladium film to a thickness of approximately $10 \mathrm{~nm}$. Samples were examined in a Hitachi S-4100 field emission scanning microscope with 7-15 mm working distance and at an acceleration voltage of $10 \mathrm{kV}$. Pictures were stored digitally and processed using EMIP 3.0. A drop of cell suspension was deposited on a grid and examined in a JEOL JEM-1010 transmission electron microscope at $60 \mathrm{kV}$ after negative staining with $2 \%(\mathrm{w} / \mathrm{v})$ phosphotungstic acid. Young $(48 \mathrm{~h})$ pure cultures of strain $2 \mathrm{SM} 4^{\mathrm{T}}$ showed a variety of cell morphologies, ranging from coccoid cells to regular rods, tear-shaped cells with polar buds and even very elongated (filamentous) cells (Fig. 1). Cell 

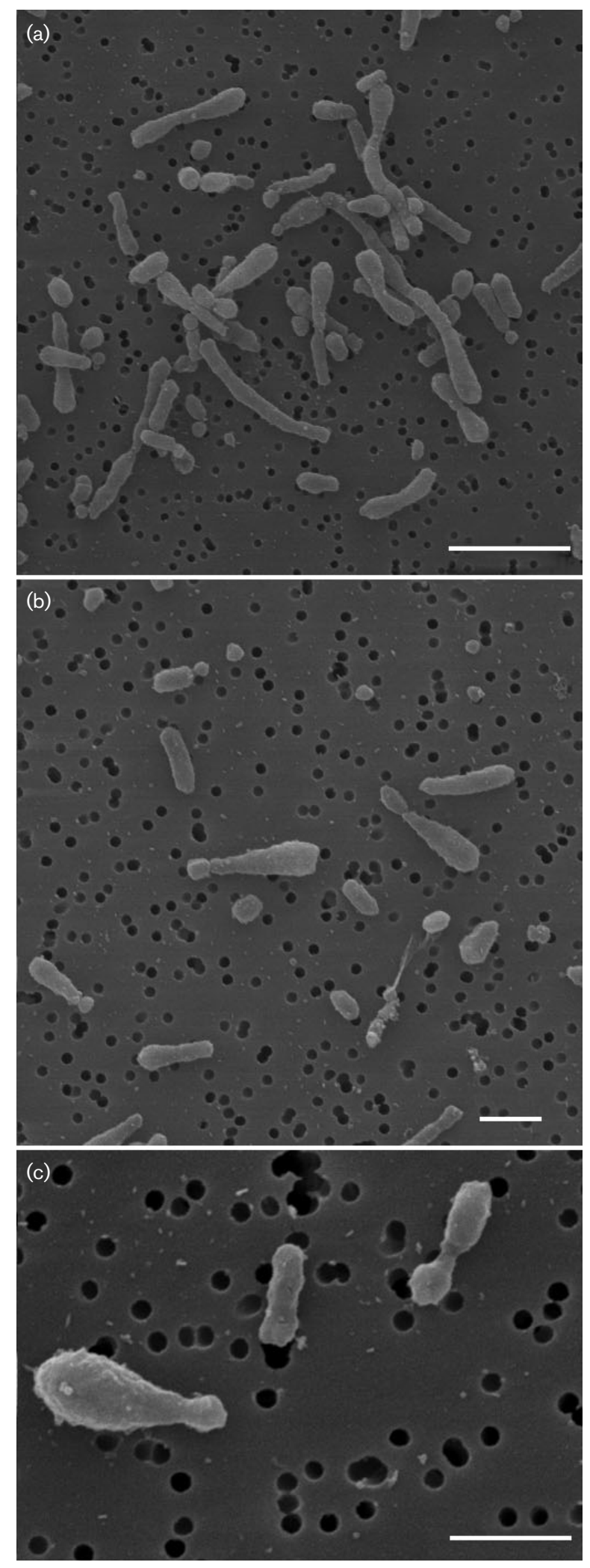

Fig. 1. Scanning electron micrographs showing the characteristic variations in cell morphology of strain $2 \mathrm{SM} 4^{\top}$. Modes of cell division can also be discerned. Additional pictures are available as supplementary figures in IJSEM Online. Bars, $2.5 \mu \mathrm{m}(\mathrm{a})$ and $1 \mu \mathrm{m}(\mathrm{b}, \mathrm{c})$. division by budding was observed in several cells, yielding almost coccoid forms, but binary fission could also be detected (Fig. 1). On wet mounts, cells were non-motile; flagella were not observed after cell staining with the method of Heimbrook et al. (1989) or by electron microscopy (see supplementary figure available in IJSEM Online). Bright granules were never observed in the cells, suggesting that poly- $\beta$-hydroxybutyrate and gas vesicles are not formed by strain $2 \mathrm{SM} 4^{\mathrm{T}}$.

The cellular fatty acid composition of strain $2 \mathrm{SM} 4^{\mathrm{T}}$, determined by GLC at the Deutsche Sammlung von Mikroorganismen und Zellkulturen (DSMZ, Braunschweig, Germany) by using a previously described method (Kämpfer \& Kroppenstedt, 1996), confirmed the affiliation of the Mediterranean isolate to the Roseobacter group. In total, only seven fatty acids were detected. The major fatty acid was $18: 1 \omega 7 c(81 \cdot 4 \%)$, followed by $18: 0(6 \%), 16: 0$ (5\%), 11-methyl $18: 1 \omega 7 c(3 \cdot 3 \%), 10: 03-\mathrm{OH}(1.9 \%)$ and $20: 1 \omega 7 c(0 \cdot 8 \%)$. In addition, a fatty acid $(1 \cdot 5 \%)$ was present that could be identified only as either $19: 1 \omega 6 c$ or 19:0 cyclo.

The $\mathrm{G}+\mathrm{C}$ content $(\mathrm{mol} \%)$ was determined by HPLC at the DSMZ, according to the procedure of Mesbah et al. (1989). The value for strain $2 \mathrm{SM} 4^{\mathrm{T}}$ was $56 \mathrm{~mol} \%$.

The 16S rRNA gene phylogeny of strain $2 \mathrm{SM} 4^{\mathrm{T}}$ was investigated by using procedures that have been reported previously (Macián et al., 2001). Almost full-length $16 \mathrm{~S}$

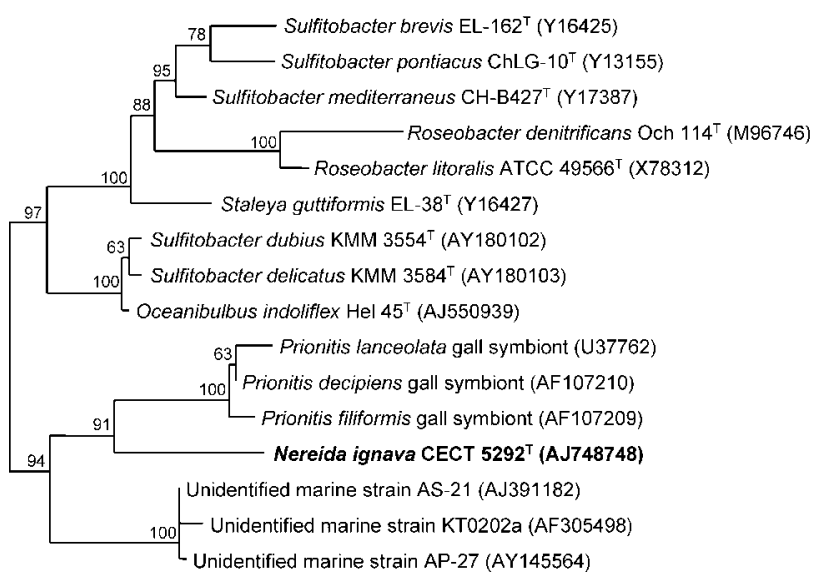

Fig. 2. Maximum-likelihood tree, as implemented in the ARB program package (Ludwig et al., 2004), based on the $16 \mathrm{~S}$ rRNA gene sequences of $N$. ignava gen. nov., sp. nov. $2 S M 4^{\top}$ and its closest relatives. For reconstruction of the tree, more than 100 almost complete sequences from type strains of species within the order 'Rhodobacterales' were included and later removed to simplify the view. Bootstrap values above $50 \%$ are shown at the nodes; percentages are based on 1000 resamplings. Bar, $5 \%$ sequence divergence. 
rRNA gene sequences were obtained using a LiCor automated sequencer (MWG Biotech) and subsequently analysed using the ARB software package (Ludwig et al., 2004). Automated sequence alignments were inspected by eye and corrected manually using the sequence editor ARB_EDIT. According to the recommendations of Ludwig et al. (1998), alternative treeing methods (maximum parsimony, maximum likelihood and distance matrix) and data subsets were employed, using the appropriate ARB tools to test the robustness of local topologies. Comparative analyses of the sequence obtained in this study established that strain $2 \mathrm{SM} 4^{\mathrm{T}}$ was phylogenetically most closely related to uncultured gall symbionts of the algal genus Prionitis, which clustered together as shown in Fig. 2. The 16S rRNA gene sequence relatedness between strain $2 \mathrm{SM} 4^{\mathrm{T}}$ and the Prionitis gall symbionts ranged from $94 \cdot 9$ to $95 \cdot 5 \%$. With respect to established species, the most similar 16S rRNA gene sequence was that of Sulfitobacter pontiacus (95.0\% sequence similarity). In addition to the large evolutionary distance that can be inferred from this value, this organism clustered in all trees examined separately from strain $2 \mathrm{SM} 4{ }^{\mathrm{T}}$ (Fig. 2). Other species belonging to the 'Alphaproteobacteria' showed even lower levels of relatedness.

Phenotypic and genetic traits that distinguish isolate $2 \mathrm{SM} 4^{\mathrm{T}}$ from its phylogenetic neighbours within the Roseobacter clade are summarized in Table 1. Differential oxidation profiles on Biolog GN plates are available in a supplementary table in IJSEM Online. All these results support the description of a novel genus and species in the 'Alphaproteobacteria', for which we propose the name Nereida ignava gen. nov., sp. nov.

\section{Description of Nereida gen. nov.}

Nereida [Ne.re.i' da. L. fem. n. Nereida (= L. fem. n. Nereis) a Nereid, a sea nymph, referring to the habitat of the bacteria].

Table 1. Phenotypic characteristics that differentiate $N$. ignava gen. nov., sp. nov. from related species

Species: 1, N. ignava; 2, Oceanibulbus indolifex; 3, Roseobacter denitrificans; 4, Roseobacter litoralis; 5, Staleya guttiformis; 6, Sulfitobacter brevis; 7, Sulfitobacter delicatus; 8, Sulfitobacter dubius; 9, Sulfitobacter mediterraneus; 10, Sulfitobacter pontiacus. Symbols: +, only positive results reported; -, only negative results reported; W, weak; ND, not determined; NG, no growth. Data are from Ivanova et al. (2004), Labrenz et al. (2000), Pukall et al. (1999), Wagner-Döbler et al. (2004) and this study.

\begin{tabular}{|c|c|c|c|c|c|c|c|c|c|c|}
\hline Characteristic & 1 & 2 & 3 & 4 & 5 & 6 & 7 & 8 & 9 & 10 \\
\hline Cell morphology & $\begin{array}{c}\text { Coccus to } \\
\text { club-shaped rod }\end{array}$ & $\begin{array}{l}\text { Irregular } \\
\quad \text { rod }\end{array}$ & $\begin{array}{l}\text { Ovoid cells } \\
\text { to rods }\end{array}$ & $\begin{array}{l}\text { Ovoid cells } \\
\text { to rods }\end{array}$ & Rod & Rod & Rod & Rod & Rod & Rod \\
\hline Pigment $^{\star}$ & $\mathrm{N}$ & $\mathrm{N}$ & $\mathrm{P}$ & $\mathrm{P}$ & $\mathrm{P} \dagger$ & $\mathrm{N}$ & $\mathrm{N}$ & $\mathrm{N}$ & $\mathrm{N}$ & $\mathrm{N}$ \\
\hline Motility & - & - & + & + & + & + & - & + & + & + \\
\hline Flagella & - & - & + & + & + & - & - & + & + & + \\
\hline $\mathrm{NO}_{3} \rightarrow \mathrm{NO}_{2}$ & - & - & + & - & + & - & $\mathrm{W}$ & + & - & + \\
\hline Salinity range $(\%, \mathrm{w} / \mathrm{v})$ & $1 \cdot 4-8$ & $1-7$ & ND & ND & $<1-4$ & $<1-8$ & $1-8$ & $1-12$ & $0 \cdot 2-8$ & $0 \cdot 5-8$ \\
\hline Growth with only $\mathrm{Na}^{+}$added & - & + & - & - & + & + & + & + & + & + \\
\hline Growth with $\mathrm{Na}^{+}, \mathrm{K}^{+}, \mathrm{Mg}^{2+}$ and $\mathrm{Ca}^{2+}$ & - & + & + & + & + & + & + & + & + & + \\
\hline \multicolumn{11}{|l|}{ Growth at: } \\
\hline $4{ }^{\circ} \mathrm{C}$ & - & - & + & $\mathrm{V}$ & - & + & - & - & + & + \\
\hline $37^{\circ} \mathrm{C}$ & - & - & - & - & - & - & + & - & - & - \\
\hline Amylase & - & - & - & - & - & - & - & - & + & + \\
\hline Gelatinase & NG & - & + & + & - & - & + & + & + & - \\
\hline Alginase & - & $\mathrm{ND}$ & - & - & - & - & + & - & - & - \\
\hline Tween 80 hydrolysis & NG & - & + & + & + & + & + & - & + & + \\
\hline Sulfite oxidation & - & ND & ND & ND & - & - & + & + & + & + \\
\hline \multicolumn{11}{|l|}{ Utilization of: } \\
\hline Melibiose & - & - & ND & ND & $\mathrm{w}$ & + & $\mathrm{ND}$ & ND & - & $\mathrm{w}$ \\
\hline Glycerol & - & + & ND & ND & + & ND & $\mathrm{ND}$ & ND & + & ND \\
\hline L-Glutamate & - & + & + & + & + & + & $\mathrm{ND}$ & ND & + & ND \\
\hline $\mathrm{L}-\alpha$-Alanine & - & + & ND & ND & + & ND & $\mathrm{ND}$ & ND & + & + \\
\hline L-Aspartate & - & + & ND & $\mathrm{ND}$ & + & ND & $\mathrm{ND}$ & ND & $\mathrm{W}$ & $\mathrm{ND}$ \\
\hline \multicolumn{11}{|l|}{ Fatty acids (\%): } \\
\hline $18: 0$ & 6 & - & $1 \cdot 3$ & $1 \cdot 2$ & $<1$ & $<1$ & - & - & $<1$ & $<1$ \\
\hline $18: 1 \omega 7 c$ 11-methyl & $3 \cdot 3$ & - & - & - & - & - & - & - & - & - \\
\hline $\mathrm{G}+\mathrm{C}$ content $(\mathrm{mol} \%)$ & 56 & $60 \cdot 1$ & $59 \cdot 6$ & $56 \cdot 3-58 \cdot 1$ & $55-56 \cdot 3$ & 58 & 60 & $63 \cdot 7$ & 59 & $62 \cdot 1$ \\
\hline
\end{tabular}

${ }^{\star} \mathrm{P}$, Pink; $\mathrm{N}$, none (colonies may appear cream, whitish, beige or brown in colour).

$\dagger$ Delayed. 
Gram-negative, strictly aerobic, chemo-organotrophic, slightly halophilic bacteria. Oxidase- and catalase-positive. Cells are coccoid to elongated rods, most of them being tear-shaped. Usually $0 \cdot 2-0 \cdot 3 \mu \mathrm{m}$ in width by $1-3 \mu \mathrm{m}$ in length; non-motile. Cells show polar budding. Slightly halophilic; no growth can be obtained without sea water or the addition of combined marine salts to the medium. Mesophilic. Neither gas vesicles nor poly- $\beta$-hydroxybutyrate accumulation is observed. Does not ferment carbohydrates and is unable to reduce nitrate to nitrite or $\mathrm{N}_{2}$. The main cellular fatty acids include $18: 1 \omega 7 c, 18: 0$ and 16:0. The genus is affiliated to the 'Alphaproteobacteria', order 'Rhodobacterales', and so far contains only one species, Nereida ignava, which is the type species. The DNA G $+\mathrm{C}$ content of the type species is $56 \mathrm{~mol} \%$.

\section{Description of Nereida ignava sp. nov.}

Nereida ignava (ig.na'va. L. fem. adj. ignava lazy).

In addition to the characteristics that define the genus, the species has the characteristics described below. It does not swarm or luminesce. Requires at least $1.36 \%(\mathrm{w} / \mathrm{v})$ marine salts and tolerates up to $8 \%(\mathrm{w} / \mathrm{v})$ salts, failing to grow at $9 \%(\mathrm{w} / \mathrm{v})$. Positive growth at 13 and $28^{\circ} \mathrm{C}$. No growth detected at 4,37 or $40^{\circ} \mathrm{C}$. Does not hydrolyse casein, starch, lecithin, alginate or agar. Does not grow in gelatin, DNA or Tween 80. Produces negative results in tests for arginine dihydrolase, lysine and ornithine decarboxylase, $\mathrm{H}_{2} \mathrm{~S}$ production from thiosulfate, indole production from tryptophan and sulfite oxidation. Utilizes the following compounds as carbon and energy sources after 14 days incubation, provided that the medium is supplemented with $0.01 \%(\mathrm{w} / \mathrm{v})$ yeast extract (an indication that undetermined growth factors are required): maltose, succinate, fumarate, malate, lactate and sarcosine. In the same conditions, it grows weakly on D-glucose, D-mannose, D-mannitol, pyruvate, propionate, acetate, citrate, $\alpha$ ketoglutarate, L-serine, L-ornithine, $\gamma$-aminobutyric acid and citrulline. The following substrates are not used: D-ribose, D-fructose, L-arabinose, D-xylose, D-galactose, D-trehalose, L-rhamnose, cellobiose, sucrose, lactose, Dmelibiose, salicin, amygdalin, D-gluconate, D-glucuronate, D-galacturonate, $\mathrm{N}$-acetylglucosamine, glycerol, D-sorbitol, meso-inositol, glycerate, cis-aconitate, DL- $\beta$-hydroxybutyrate, $p$-hydroxybenzoate, D-saccharic acid, glycine, L-leucine, L-arginine, L-alanine, L-glutamate, L-threonine, L-aspartate, L-lysine, L-tyrosine, L-histidine and putrescine.

The type strain, $2 \mathrm{SM} 4^{\mathrm{T}}\left(=\mathrm{CECT} 5292^{\mathrm{T}}=\mathrm{DSM} 16309^{\mathrm{T}}=\mathrm{CIP}\right.$ $108404^{\mathrm{T}}=$ CCUG $49433^{\mathrm{T}}$ ), was isolated from Mediterranean sea water off Valencia (Spain).

\section{Acknowledgements}

Thanks are due to J. M. López, Colección Española de Cultivos Tipo (CECT), for his assistance with bioinformatic issues. This work was partially supported by the Deutsche Forschungsgemeinschaft and by project AGL-2002-04075-C02-C02 of the Spanish Ministerio de
Ciencia y Tecnología. D. R. A. has a contract with the Universitat de València under the Ramón y Cajal program (Ministerio de Ciencia y Tecnología).

\section{References}

Ashen, J. B. \& Goff, L. J. (1996). Molecular identification of a bacterium associated with gall formation in the marine red alga Prionitis lanceolata. J Phycol 32, 286-297.

Ashen, J. B. \& Goff, L. J. (1998). Galls on the marine red alga Prionitis lanceolata (Halymeniaceae): specific induction and subsequent development of an algal-bacterial symbiosis. Am J Bot 85, 1710-1721.

Ashen, J. B. \& Goff, L. J. (2000). Molecular and ecological evidence for species specificity and coevolution in a group of marine algalbacterial symbioses. Appl Environ Microbiol 66, 3024-3030.

Baumann, P. \& Baumann, L. (1981). The marine gram-negative eubacteria: genera Photobacterium, Beneckea, Alteromonas, Pseudomonas and Alcaligenes. In The Prokaryotes, vol. II, pp. 1302-1331. Edited by M. P. Starr, H. Stolp, H. G. Trüper, A. Balows \& H. Schlegel. Berlin: Springer.

Benlloch, S., Rodríguez-Valera, F. \& Martinez-Murcia, A. J. (1995). Bacterial diversity in two coastal lagoons deduced from $16 \mathrm{~S}$ rDNA PCR amplification and partial sequencing. FEMS Microbiol Ecol 18, 267-279.

Bowman, J. P., McCammon, S. A., Brown, M. V., Nichols, D. S. \& McMeekin, T. A. (1997). Diversity and association of psychrophilic bacteria in Antarctic sea ice. Appl Environ Microbiol 63, 3068-3078.

Garrity, G. M., Bell, J. A. \& Lilburn, T. G. (2003). Taxonomic outline of the procaryotes. In Bergey's Manual of Systematic Bacteriology, 2nd edn, release 4.0. New York: Springer. doi:10.1007/bergeysoutline200310

Gonzalez, J. M., Mayer, F., Moran, M. A., Hodson, R. E. \& Whitman, W. B. (1997). Sagittula stellata gen. nov., sp. nov., a lignintransforming bacterium from a coastal environment. Int J Syst Bacteriol 47, 773-780.

Gonzalez, J. M., Kiene, R. P. \& Moran, M. A. (1999). Transformation of sulfur compounds by an abundant lineage of marine bacteria in the $\alpha$-subclass of the class Proteobacteria. Appl Environ Microbiol 65, 3810-3819.

Gonzalez, J. M., Simo, R., Massana, R., Covert, J. S., Casamayor, E. O., Pedros-Alio, C. \& Moran, M. A. (2000). Bacterial community structure associated with a dimethylsulfoniopropionate-producing North Atlantic algal bloom. Appl Environ Microbiol 66, 4237-4246.

Gosink, J. J. \& Staley, J. T. (1995). Biodiversity of gas vacuolate bacteria from Antarctic Sea ice and water. Appl Environ Microbiol 61, 3486-3489.

Heimbrook, M. E., Wang, W. L. L. \& Campbell, G. (1989). Staining bacterial flagella easily. J Clin Microbiol 27, 2612-2615.

Ivanova, E. P., Gorshkova, N. M., Sawabe, T. \& 8 other authors (2004). Sulfitobacter delicatus sp. nov. and Sulfitobacter dubius sp. nov., respectively from a starfish (Stellaster equestris) and sea grass (Zostera marina). Int J Syst Evol Microbiol 54, 475-480.

Kämpfer, P. \& Kroppenstedt, R. M. (1996). Numerical analysis of fatty acid patterns of coryneform bacteria and related taxa. Can J Microbiol 42, 989-1005.

Labrenz, M., Tindall, B. J., Lawson, P. A., Collins, M. D., Schumann, P. \& Hirsch, P. (2000). Staleya guttiformis gen. nov., sp. nov. and Sulfitobacter brevis sp. nov., $\alpha$-3-Proteobacteria from hypersaline, heliothermal and meromictic antarctic Ekho Lake. Int J Syst Evol Microbiol 50, 303-313. 
Ludwig, W., Strunk, O., Klugbauer, S., Klugbauer, N., Weizenegger, M., Neumaier, J., Bachleitner, M. \& Schleifer, K.-H. (1998). Bacterial phylogeny based on comparative sequence analysis. Electrophoresis 19, 554-568.

Ludwig, W., Strunk, O., Westram, R. \& 29 other authors (2004). ARB: a software environment for sequence data. Nucleic Acids Res 32, 1363-1371.

Macián, M. C., Ludwig, W., Schleifer, K. H., Garay, E. \& Pujalte, M. J. (2001). Thalassomonas viridans gen. nov., sp. nov., a novel marine $\gamma$-proteobacterium. Int J Syst Evol Microbiol 51, 1283-1289.

Macián, M. C., Arahal, D. R., Garay, E., Ludwig, W., Schleifer, K. H. \& Pujalte, M. J. (2005). Thalassobacter stenotrophicus gen. nov., sp. nov., a novel marine $\alpha$-proteobacterium isolated from Mediterranean sea water. Int J Syst Evol Microbiol 55, 105-110.

Mesbah, M., Premachandran, U. \& Whitman, W. B. (1989). Precise measurement of the $\mathrm{G}+\mathrm{C}$ content of deoxyribonucleic acid by highperformance liquid chromatography. Int J Syst Bacteriol 39, 159-167.
Ortigosa, M., Garay, E. \& Pujalte, M. J. (1994). Numerical taxonomy of aerobic, Gram-negative bacteria associated with oysters and surrounding seawater of the Mediterranean coast. Syst Appl Microbiol 17, 589-600.

Pukall, R., Buntefuß, D., Frühling, A., Rohde, M., Kroppenstedt, R. M., Burghardt, J., Lebaron, P., Bernard, L. \& Stackebrandt, E. (1999). Sulfitobacter mediterraneus sp. nov., a new sulfiteoxidizing member of the $\alpha$-Proteobacteria. Int J Syst Bacteriol 49, 513-519.

Rappé, M. S., Connon, S. A., Vergin, K. L. \& Giovannoni, S. J. (2002). Cultivation of the ubiquitous SAR11 marine bacterioplankton clade. Nature 418, 630-633.

Wagner-Döbler, I., Rheims, H., Felske, A., El-Ghezal, A., FladeSchröder, D., Laatsch, H., Lang, S., Pukall, R. \& Tindall, B. J. (2004). Oceanibulbus indolifex gen. nov., sp. nov., a North Sea alphaproteobacterium that produces bioactive metabolites. Int J Syst Evol Microbiol 54, 1177-1184. 